\title{
Hubungan Pola Asuh Orang Tua terhadap Kemandirian Anak Usia Dini di RA X
}

\author{
Safitri Hutami*, Ayi Sobarna \\ Prodi Pendidikan Guru PAUD, Fakultas Tarbiyah dan Keguruan, \\ Universitas Islam Bandung, Indonesia. \\ *safitrihutami08@gmail.com, ayiobarna948@gmail.com
}

\begin{abstract}
Educating children through the parenting approach is aimed at the children's success in the future, though parents' status and education are influential in educating early childhood. Those determine the children's parenting pattern in independence education. Because children's independence is necessary for them, so they can do things without help. The aims of this study are (1) determining the students' independence level at Nabila Islamic early childhood education; and (2) understanding the relationship between parenting approaches in creating the students' independence early childhood at Nabila Islamic early childhood education. This research uses a quantitative method with a correlational approach. in addition, the researcher uses this method, for the researcher will discuss two interrelated variables to test the current hypothesis. The results of the study are (1) the lowest value of parents' parenting approach is at 8 , and the highest value is at 15 . The average value is 12.26 and, the standard deviation is 1.65 ; and (2) in addition, the Independence value shows $30.0 \%$ in the high category, $50 \%$ in the medium category, and $20.0 \%$ in the low category. Looking at the previous value, the researcher hopes this research is able to help parents in understanding the importance of parenting aspects inside of a family. in addition, parents should adjust the parenting applied in their family by adopting appropriate parenting patterns, in order to increase the independence of early childhood and instil noble values in forming children's independence and character.
\end{abstract}

Keywords: Parenting,Independence, childhood..

Abstrak. Mendidik anak dengan pola pengasuhan dapat diberikan orang tua pada anaknya sebaikbaiknya agar menjadi anak yang berguna walaupun status pekerjaan dan pendidikan orang tua berpengaruh dalam mendidik anak usia dini. Hal ini melatar belakangi khususnya pola asuh yang diberikan orang tua kepada anak mengenai kemandirian. Sebab kemandirian sangatlah penting bagi anak, karena anak mampu melakukan suatu hal tanpa bantuan. Penelitian ini bertujuan untuk (1) Untuk mengetahui tingkat kemandirian Anak Usia Dini di RA X (2) Untuk mengetahui hubungan pola asuh orang tua dalam membentuk kemandirian Anak Usia Dini di RA X. Penelitian ini menggunakan jenis penelitian kuantitatif dan memakai pendekatan korelasional, metode ini dipilih karena berdasarkan judul penelitian, peneliti akan membahas dua variabel yang saling terhubung, yang bertujuan untuk menguji hipotesis yang ditetapkan sebelumnya. Hasil penelitian yang dapat disajikan sebagai berikut : (1) Pola Asuh Orang Tua, mendapat nilai terendah sebesar 8, nilai tertinggi 15 , nilai rata-rata sebesar 12.26 serta simpangan baku sebesar 1.65. (2) Kemandirian diperoleh temuan penelitian bahwa dari 30 responden penelitain terdapat 9 (30.0\%) responden yang memiliki kemandirian dengan kategori tinggi, $15(50 \%)$ responden yang memiliki kemandirian dengan kategori sedang, serta $6(20.0 \%)$ responden dengan kategori kemandirian dengan kategori rendah. Serta saran yang diberikan yaitu diharapkan dari hasil penelitian diharapkan dapat membantu orang tua untuk memahami bahwa pentingnya mengasuh anak dalam keluarganya guna menanamkan nilai-nilai dan meningkatkan kemandirian anaknya. Pada temuan studi, agar orang tua dapat menyesuaikan pola asuh yang diterapkan pada keluarganya dengan menerapkan pola asuh yang sesuai dalam rangka meningkatkan kemandirian anak usia dini menanamkan nilai-nilai luhur.

Kata Kunci: pola asuh,kemandirian,anak. 


\section{A. Pendahuluan}

Perkembangan pada aspek sosial emosional, merupakan hal yang utama dan penting dalam kehidupan seorang anak, terutama adalah pembentukan kepribadian yang bersifat mandiri. Kemandirian memainkan peran yang penting di masa kecil. Artinya, membiarkan anak melakukan sesuatu sendiri tanpa bantuan. Fadhillah dan Khorida (2013). Menurut hlm.195, kemandirian adalah antara lain "kemerdekaan dari urusan orang lain" untuk mencegah anak menjadi beban bagi orang-orang di sekitarnya. Sangat penting untuk menerapkan pelatihan kepribadian mandiri kepada setiap individu sejak usia dini.

Hal ini disebabkan terbentuknya kepribadian yang mandiri di setiap masing-masing individu, yang dapat mengurangi terjadinya perilaku menyimpang dan sering terjadi saat ini pada anak usia 5-6 tahun. Seorang anak laki-laki berusia 6 tahun memukuli teman seorang anak laki-laki karena tidak diajak oleh temannya untuk bermain. Mencuci tangan tanpa izin, mencuci tangan setelah makan, makan kotor, berbicara, makan tidak teratur, tidak bisa mengikat tali sepatu, tidak tahu cara memakai sepatu, beberapa anak bingung memakai sepatu.

Dapat dikatakan tidak membentuk karakter mandiri pada anak, Karena jika anak memantapkan kemandiriannya, anak tidak berani melakukan sesuatu diluar hal yang menyimpang. Lingkungan didalam keluarga, khususnya perilaku orang tua terhadap anak, hal yang utama mempengaruhi dan membentuk perkembangan kepribadian anak, termasuk pembentukan dan pelaksanaan kepribadian mandiri pada anak sejak bayi sampai usia dewasa.

Secara umum, ada tiga. Salah satunya adalah otoriter, di mana perilaku orang tua sepenuhnya mengatur aktivitas anak dan aturan yang ditetapkan orang tua harus dihormati sepenuhnya oleh anak. Bentuk pola asuh kedua adalah demokrasi. Dorongan dan motivasi anak untuk melakukan apa yang mereka inginkan.

Demokrasi ada dalam keadaan tidak adanya ketegasan dan kontrol atas hubungan orang tua dan anak dan tanpa adanya aturan. Ketiga, pola asuh yang toleran, yaitu perlakuan orang tua yang memberikan kebebasan penuh kepada anaknya dalam beraktivitas dan tidak ada kontrol atau aturan keluarga. Orang tua melakukannya dengan baik. Setiap anak diperlakukan berbeda, tetapi setiap gaya pengasuhan memiliki kekuatan dan kelemahannya. Hal ini tentunya berdampak besar terhadap sikap anak, baik di rumah, di sekolah maupun di masyarakat dan melatih kepribadian mandiri anak.

Anak mampu menjadi mandiri jika anak dapat menyadari potensi nya. Hal ini karena kualitas lingkungan rumah merupakan cara bagi anak untuk mencapai perkembangan yang matang seiring bertambahnya usia, terutama dari sudut pandang mandiri. Anak mungkin menghadapi banyak tantangan dalam hidup di masa depan. Jika pola asuh dan dorongan orang tua tidak tepat untuk anak, maka dapat melakukan kesalahan, anak tidak dapat beradaptasi di luar keluarga, atau mungkin memiliki karakter manja dan mandiri.

Ada beberapa aspek kemandirian ialah kemandirian emosi, kemandirian bertindak, serta kemandirian berpikir (Lestari, 2019, hal. 84-85). Kemandirian emosi berhubungan dalam menjalin sebuah interaksi dengan orang lain dan cara anak mengatur emosi nya. Kemandirian intelektual berkaitan dengan bagaimana anak mengatasi masalah dengan memperhatikan nilai dan norma yang berlaku di lingkungannya. Perilaku mandiri berkaitan dengan perkembangan fisik yang dialami anak-anak dan bagaimana mereka menentukan apa yang harus dilakukan dengan percaya diri dan tanggung jawab. Setiap anak memiliki tingkat kemandirian yang berbeda. Hal ini karena berbagai yaitu faktor internal dan eksternal. Faktor internal semuanya berasal dari keadaan psiko-fisiologis anak. Faktor ekstrinsik berasal dari gen orang tua, pola asuh, dan sistem pendidikan.

Dari kutipan di atas, kita diketahui bahwa sikap orang tua selaras dengan pola asuh ketika berinteraksi dengan anaknya. Saat ini, banyak orang tua mengadopsi gaya pengasuhan yang berbeda. Dengan kata lain, ada beberapa jenis yaitu otoriter, permissive, demokratis. Menurut Hasan (2009:26) 'Pola asuh demokratis adalah model pengasuhan yang sepenuhnya menerima dan melibatkan anak, dengan keterbatasan, dan anak berperilaku pada tingkat kemampuan dan perkembangan anak, dipandu oleh kehangatan, kasih sayang, dan komunikasi dua arah'. Tipe orang tua ini dicirikan oleh kenyataan bahwa orang tua menganggap anaknya menjadi individu yang mampu berkembang sendiri dan memiliki sikap inisiatif, orang tua 
memiliki kemandirian untuk pengambilan keputusan didasarkan atas kesepakatan bersama. Apabila divisualkan akan terlihat tampak hubungan pola asuh terhadap kemandirian anak usia dini. Berdasarkan hal tersebut, peneliti tertarik untuk meneliti apa yang membuat tingkat kemandirian anak disekolah hasil dari pola asuh orang tua dirumah sudah cukup baik dan berkembang apabila anak- anak berada dilingkungan sekolah. Termasuk juga pada anak usia 46 tahun di RA X. Salah satu hal penting mengenai masa perkembangan anak yaitu fase otonomi. Fase antusiasme untuk melakukan segala hal sendiri dan munculnya keingin tahuan anak. Suryadi (2019) 'kemandirian bukanlah karakter yang muncul tiba-tiba, sangat perlu sekali diajarkan pada anak. Apabila anak tidak belajar mandiri sejak usia dini, anak sangat akan tidak mengetahui bagaimana harus membantu diri sendiri'. 'Pembiasaan (habituation) ialah proses pembentukan sikap perilaku yang relatif tetap dan bersifat tiba-tiba dalam pendidikan menurut Surifah, dkk (2018)'.

Perilaku yang menjadi kebiasaan adapun ciri yakni perilaku tersebut relatif tetap, tidak membutuhkan fungsi berpikir yang cukup tinggi. Kemandirian merupakan aspek yang berkembang dalam diri setiap individu, yang bentuknya sangat beragam, tergantung pada proses perkembangan dan proses belajar yang dialami masing-masing individu. Oleh karena itu, kemandirian memiliki pemgertian suatu penghayatan/ semangat untuk menjadi lebih baik dan percaya diri, mengolah pikiran untuk mempelajari masalah dan membuat keputusan untuk bertindak, disiplin dan tanggung jawab serta tidak bergantung kepada orang lain. Dimana pola asuh dirumah yang diterapkan dapat menghasilkan anak yang mandiri di sekolah.

Peneliti melakukan observasi awal di RA X dengan melakukan wawancara kepada kepala sekolah di sekolah tersebut. Dari hasil observasi tersebut dapat diketahui bahwa anakanak sudah mampu membereskan mainannya sendiri, sudah mampu ke kamar mandi sendiri, mampu meletakan sepatu di raknya, dan berani berangkat sekolah tanpa di tunggu oleh orang tua mereka. Sehingga dapat disimpulkan bahwa tingkat kemandirian anak di sekolah RA X sudah baik dan sudah mencapai tahap usianya. Hal tersebut dapat dilihat melalui observasi penilaian harian, catatan anekdot, dan lembar portofolio yang dilakukan oleh guru setiap harinya mengenai sosial emosional anak.

Berdasarkan hal tersebut, peneliti tertarik untuk meneliti apa yang membuat tingkat kemandirian anak disekolah hasil dari pola asuh orang tua dirumah sudah cukup baik dan berkembang apabila anak- anak berada dilingkungan sekolah. Termasuk juga pada anak usia 46 tahun di RA X. Salah satu hal penting mengenai masa perkembangan anak yaitu

Maka, kemandirian yaitu mengelola pikiran untuk menjadi lebih baik dan percaya diri, memecahkan masalah, bertindak, disiplin, bertanggung jawab dan membuat keputusan independen dari orang lain. Dimana pola asuh dirumah yang diterapkan dapat menghasilkan kemandirian anak disekolah. Kemandirian dapat diwujudkan dengan cara melakukan sesuatu yang diinginkannya tanpa meminta tolong kepada orang lain, mengukur kemampuan untuk mengarahkan kelakuannya tanpa patuh kepada orang lain, bertanggung jawab, dan mempunyai emosi yang stabil. Mendidik anak dengan pola pengasuhan yang diberikan orang tua kepada anaknya sebaik- baiknya agar anak menjadi anak yang berguna walaupun status pekerjaan dan pendidikan orang tua yang berpengaruh dalam mendidik anak usia dini. Hal ini melatar belakangi khususnya pola pengasuhan orang tua kepada anak mengenai kemandirian. Sebab kemandirian sangatlah penting bagi anak, karena anak mampu melakukan suatu hal tanpa bantuan.

Dari hasil observasi langsung di RA X anak usia dini memiliki karakter yang mandiri, dikatakan mandiri karena beberapa anak-anak di RA X memiliki kriteria yang sesuai dengan karakteristik kemandirian pada usianya seperti mampu melakukan sesuatu sendiri tanpa dibantu oleh orang lain, memiliki karakter tanggung jawab, mampu berbagi dengan temannya, bermain dengan teman seusianya. Andriasih (2019) menyatakan otonomi (kemandirian) anak usia dini terapat karakteristik seperti mempunyai keyakinan, motivasi, berani menentukan pilihan, kreatif, tanggung jawab, beadaptasi, bisa melakukan segala sesuatu sendiri dan hal ini jelas mampu mencapai tujuan pengasuhan.

Peneliti mengobservasi di TK RA X karena peneliti tertarik mengenai konsep pengasuhan yang diberikan oleh orang tua mengenai kemandirian di TK RA X, maka itu peneliti 
melakukan survei mengenai konsep pengasuhan dalam upaya meningkatkan kemandirian anak. Berdasarkan hal tersebut, peneliti mengambil judul "Hubungan Pola Asuh Orang Tua Terhadap Kemandirian Anak Usia Dini di RA X".

\section{B. Metodologi Penelitian}

Penelitian ini menggunakan metode penelitian kuantitatif deskriptif. Jenis untuk mendeskripsikan data atau menggambarkan data untuk menganalisi data. Penelitian kuantitatif deskriptif memakai pendekatan korelasi (correlational research). Penelitian korelasi yaitu penelitian yang dapat dilakukan untuk menemukan ada dan tidaknya hubungan,apabila ditemukan ada seberapa eratkah hubungan serta penting atau tidak hubungan itu. Penelitian korelasi memperlajari dua variabel atau lebih yakni sejauh mana variasi dalam satu variabel berhubungan dengan variasi dalam variabel lain.

Teknik pengumpulan data yang akan digunakan dalam penelitian ini adalah angket/ kuesioner, Populasi dalam penelitian ini yaitu orang tua dari anak kelas A dan B RA X. Sedangkan sampel, peneliti menggunakan teknik stratified random sampling. Metode Stratified Random Sampling merupakan proses pengambilan sampel yang melalui proses pembagian populasi ke dalam strata, menggunakan sampel acak sederhana dari setiap stratum, dan mengabungkan ke sampel untuk digunakan dalam parameter populasi.

\section{Hasil Penelitian dan Pembahasan}

Statistik deskripif ini digunakan dalam analisis data melalui metode pendeskripsian atau penggambaran dari data-data yang sudah terkumpul apakah sudah selaras dengan keadaan yang terjadi sebenarnya guna memberi keputusan yang umum atau general. Statistic deskriptif dapat dipakai apabila peneliti hanya ingin mendeskripsikan data sampel dan tidak ingin membuat kesimpulan yang berlaku untuk populasi yang berpotensi sebagai sampel.

Pengasuhan atau sering disebut dengan pola asuh secara umum orangtua memperlakukan anak, mendidik, membimbing dan mendisiplinkan serta melindungi anak dalam mencapai proses kedewasaan.

Berdasarkan tabel yang disajikan, diperoleh temuan penelitian bahwa dari 30 responden penelitian yang mengisi instrumen angket Pola Asuh Orang Tua, diperoleh nilai terendah sebesar 8 , nilai tertinggi 15 , nilai rata-rata sebesar 12.26 serta simpangan baku sebesar 1.65 . yang kemudian berdasarkan tabel tersebut dapat disajikan tabel distribusi frekuensi pola asuh orang tua.

Berdasarkan tabel distribusi frekuensi yang disajikan, diperoleh temuan penelitian bahwa dari 30 responden penelitain terdapat $8(26.7 \%)$ responden yang memiliki pola asuh dengan kategori tinggi, 16 (53.3\%) responden yang memiliki pola asuh dengan kategori sedang, serta $6(20.0 \%)$ responden dengan kategori pola asuh dengan kategori rendah. Yang kemudian dapat divisualiasikan dengan menggunakan histogram. Pada Berdasarkan histogram yang disajikan di atas, dapat diketahui bahwa frekuensi tertinggi terdapat pada kategori sedang, dan frekuensi terendah terdapat pada pola asuh orang tua dengan kategori rendah.

Berdasarkan tabel distribusi frekuensi yang disajikan, diperoleh temuan penelitian bahwa dari 30 responden penelitain terdapat $6(20 \%)$ responden memiliki pola asuh orang tua dengan kategori permisif, dan $24(80 \%)$ responden penelitian memiliki pola asuh orang tua demokratis.

Berdasarkan tabel uji normalitas dengan menggunakan uji kolmogorov smirnov yang disajikan di atas diperoleh temuan penelitian bahwa data penelitian pola asuh orang tua serta data kemandirian anak usia dini mempunyai sebaran data yang berdistribusi normal, temuan ini dibuktikan dengan koefisien asimsig $=0.346$ serta 0.216 yang keseluruhan lebih besar dibandingkan dengan taraf signifikansi alpha yang telah ditentukan yaitu sebesar 0.05 .

Berdasarkan hasil uji liniearitas dengan menggunakan software IBM for SPSS versi 20 yang disajikan di atas, diperoleh temuan pneelitain bahwa variabel kemandirian dan variabel pola asuh orang tua memiliki hubungan yang linier, temuan ini dibuktikan dengan koefisien sig pada linierity memiliki koefisien sebesar 0.003 yang secara statistik lebih kecil dibandingkan dengan taraf signifikansi alpha yang telah ditentukan yaitu sebesar 0.05. 
Berdasarkan hasil pengujian hipotesis dengan menggunakan uji pearson product moment yang disajikan, diperoleh temuan penelitian bahwa terdapat hubungan yang sinifikan dan positif antara pola asuh orang tua dan kemandirian anak usia dini, temuan ini dibuktikan dengan koefisien sig $=0.005<0.05$ serta koefisien pearson sebesar 0.503 , yang berarti bahwa semakin baik pola asuh yang diberikan oleh orang tua, maka akan semakin baik (meningkat) pula kemandirian yang dimiliki oleh anak usia dini, dan namun sebaliknya, semakin rendah pola asuh yang diberikan, maka akan semakin rendah pula kemandirian yang dimiliki oleh anak usia dini. selain itu hubungan antara pola asuh orang tua dan kemandirian anak termasuk dalam korelasi moderat di buktikan koefisien pearson sebesar 0.503 yang berada diantara kategori 0,40 sampai 0,59 hingga masuk dalam kategori koefesien moderat. Berdasarkan hasil pengujian hipotesis penelitian menggunakan uji pearson product moment diperoleh temuan penelitian bahwa terdapat hubungan yang signifikan antara pola asuh orang tua dalam membentuk kemandirian Anak Usia Dini di RA X, temuan ini dibuktikan dengan koefisien sig $=0.005<$ 0.05 serta koefisien pearson sebesar 0.503 , yang berarti bahwa semakin baik pola asuh yang diberikan oleh orang tua, maka akan semakin baik (meningkat) pula kemandirian yang dimiliki oleh anak usia dini, dan sebaliknya, semakin rendah pola asuh yang diberikan, maka akan semakin rendah pula kemandirian yang dimiliki oleh anak usia dini.

Temuan penelitian ini sejalan dengan pendapat yang telah disampaikan oleh Hurlock (dalam Menuk : 2009) yang menyakatan bahwa 'Faktor-faktor yang dapat Mempengaruhi Kemandirian tidak melekat pada diri individu sejak lahir, melainkan perkembangannya dipengaruhi oleh berbagai stimulasi yang datang dari lingkungannya, selain potensi yang telah dimiliki sejak lahir sebagai keturunan dari orang tuanya. Pemberian stimulasi yang sesuai dan teratur di lingkungan keluarga, anak akan lebih mandiri dibanding dengan anak yang kurang dalam stimulasi'.

Perlakukan khusus yang berlebih pada anak dapat mempengaruhi anak menjadi manja, bila ayah dan ibu bekerja tetap harus mendidik anak dengan baik dan benar. Kunci utama keberhasilan anak adalah pola asuh orang tua yang diberikan agar menjadi seorang anak yang disipin, memiliki rasa percaya diri dan mandiri.

Temuan penelitian ini juga sejalan dengan penelitian yang telah dilakukan oleh Ummi Nurl Hikmah (2012) dengan judul penelitain Pengaruh Pola Asuh Orang Tua Terhadap Kemandirian Anak Usia Dini Di Ra Perwanida 01 Boyolali Tahun Ajaran 2011/2012. Dengan Tujuan penelitian ini adalah untuk mengetahui pengaruh pola asuh orang tua dengan kemandirian anak usia dini di RA Perwanida 01 Boyolali Tahun Ajaran 2011/2012. Metode ini memakai deskriptif korelasional. Penelitian dilakukan di RA Perwanida 01 Boyolali. Populasi pada penelitian tersebut yait semua anak di RA Perwanida 01 Boyolali sebanyak 199 anak. Peneliti mengambil sampel sebanyak 50 anak dengan menggunakan teknik proporsional random sampling. Data pola asuh orang tua didapatkan melalui angket, sedangkan data kemandirian anak didapatkan melalui observasi. Teknik analisis data yang digunakan adalah analisis korelasi product moment. Hasil analisis data menunjukkan bahwa pola asuh orang tua (X) mempunyai pengaruh yang signifikan terhadap kemandirian anak usia dini (Y). Hal ini dapat dilihat dari hasil analisis data yang menunjukkan rxy > rtabel atau 0,913>0,279 (taraf signifikan 5\%) yang berarti ada pengaruh antara pola asuh orang tua terhadap kemandirian anak usia dini.

\section{Kesimpulan}

Berdasarkan pembahasan dalam penelitian ini, peneliti menyimpulkan hasil penelitian sebagai berikut:

Terdapat hubungan yang sinifikan dan positif antara pola asuh orang tua dan kemandirian anak usia dini, temuan ini dibuktikan dengan koefisien sig $=0.005<0.05$ serta koefisien pearson sebesar 0.503 , yang berarti bahwa semakin baik pola asuh yang diberikan oleh orang tua, maka akan semakin baik (meningkat) pula kemandirian yang dimiliki oleh anak usia dini, dan sebaliknya, semakin rendah pola asuh yang diberikan, maka akan semakin rendah pula kemandirian yang dimiliki oleh anak usia dini. 


\section{Acknowledge}

Puji dan syukur dipanjatkan kehadirat Allah SWT, karena atas ridha dan karunia-Nya maka skripsi yang berjudul "Hubungan Pola Asuh Orang Tua Terhadap Kemandirian Anak Usia Dini" telah diselesaikan. Penelitian skripsi ini diajukan untuk menempuh gelar sarjana pada program studi PG-PAUD, Fakultas Tarbiyah dan Keguruan, Universitas Islam Bandung. Tugas akhir ini dapat diselesaikan tidak lepas dari bantuan dan kerjasama dengan pihak lain. Berkenaan dengan hal tersebut, peneliti menyampaikan ucapan terima kasih kepada:

1. Ibu Dr. Erhamwilda, Dra., M.Pd. selaku Dosen Pembimbing I dan Bapak Ayi Sobarna, Drs., M.Pd. selaku Dosen Pembimbing II yang telah meluangkan waktu, tenaga dan pikirannya untuk membantu dan mengarahkan peneliti dalam proses penyusunan skripsi ini.

2. Bapak Enoh, Drs., M.Ag. selaku Dekan Fakultas Tarbiyah dan Keguruan Universitas Islam Bandung.

3. Ibu Dr. Erhamwilda, Dra., M.Pd. selaku Ketua Program Studi PG PAUD Fakultas Tarbiyah dan Keguruan Universitas Islam Bandung.

\section{Daftar Pustaka}

[1] (n.d.). http://repository.radenintan.ac.id/1669/5/Bab_II.pdf.

[2] (Partisipasi Orangtua dalam Pendidikan Anak. Jurnal al-Kalam Vol. IX No. 2 - Desember 2017. (2017).

[3] (2006). PARTISIPASI ORANGTUA TERHADAP PENDIDIKAN ANAK USIA DINI: SURVEI PADA KELOMPOK BERMAIN DI KOTA YOGYAKARTA.

[4] Agustiawati, I. (2014). Pengaruh pola asuh orangtua terhadap prestasi belajar siswa pada mata pelajaran Akuntansi.

[5] Amini, M. (2014). PENINGKATAN KETERLIBATAN ORANG TUA DALAM MENDIDIK ANAK USIA DINI MELALUI PENDAMPINGAN 'PARENTING CLASS' (PENGEMBANGAN MODEL DI TK TANGERANG SELATAN).

[6] Andriasih, N. G. (2019). The Implementation of Scientific Approach-Based Project Learning Method to Stimulate The Early Child's Autonomy. 3(1). Journal of Psychology and Instruction, 1-6.

[7] Anshori, M. \&. (2009). Metodologi Penelitian Kuantitatif. Surabaya: Airlangga University Press.

[8] Darmawan, D. (2014). Metode Penelitian Kuantitatif. Bandung: PT Remaja Rosdakarya.

[9] Diadha, R. (2015). KETERLIBATAN ORANG TUA DALAM PENDIDIKAN ANAK.

[10] Edusentris, J. I. (2015). Jurnal Ilmu Pendidikan dan Pengajaran, .

[11] https://legaldictionary.net/parenting-classes/. (n.d.).

[12] Junita, K. (2014). EFEKTIVITAS PENERAPAN PRINSIP KOMUNIKASI ISLAM GURU DALAM PEMBINAAN KARAKTER SISWA KELAS X SMK NAMIRA MEDAN . INFORMATIKA, 10-33.

[13] Lestari, M. (2019). Hubungan Pola Asuh Orang Tua dengan Kemandirian Anak. Jurnal Pendidikan Anak, 8 (1). Retrieved April 20, 2021, from https://journal.uny.ac.id/index.php/jpa 